\title{
The Relationship between Mall Attributes and Customer Loyalty: The Mediating Effect of Shopping Value. By
}

Ahmed Samir Roushdy

Sadat Academy for Management Sciences King Abdul-Aziz University

\begin{abstract}
:
The aim of the current study is to discover the impact of mall attributes on customer loyalty through the mediating effect of shopping values (Hedonic \& Utilitarian values).In this study mall attributes comprises seven factors which are products ,atmosphere, social interaction with other customers ,convenience, service ,price, social interaction with employees. Mall intercept interviews are conducted to collect data at three shopping malls in a great Cairo in Egypt. PLS-SEM is implemented for testing the hypotheses.

The findings indicate that most mall attributes (atmosphere, social interaction with employees, and social interaction with other customers) have a significant and positive effect on hedonic shopping value. The results also indicated that only atmosphere and convenience have a significant and positive impact on utilitarian shopping value. Findings also showed that most mall attributes (social interaction with employees, interaction with other customers, convenience, service, and price) were found to affect positively and significantly the customers' loyalty. The results also showed that only hedonic shopping value significantly and positively influences customers' loyalty. Therefore, only hedonic shopping
\end{abstract}


value has a partial mediation effect between some mall attributes (atmosphere, social interaction with employees and social interaction with other customers) and loyalty.

The results of this study provide the shopping malls in Egypt with a specific knowledge of the mall attributes that will affect the shopping value and consequently the customer loyalty, and suggest some useful marketing strategy implications for them in order to compete in this market. On the other hand the current research develops and empirical validate of a hypothetical model that predicts the relationship between mall attributes, shopping value, and customer loyalty.

\section{Introduction:}

Nowadays, shopping malls have an important role in social activities and lifestyles of consumers (Terblanche, 1999). With the growing number of shopping malls, customers have become more selective. Features that attract some customers may not attract others (El-Adly, 2007). Thus, shopping malls managers should understand satisfaction with mall attributes and customers' satisfaction with the mall shopping experience about all of these attributes specially with this highly competitive environment (Machleit et al., 2005).

Michon and Chebat (2004) stated that shopping value representing the benefits resulted in the shopping experience and deduces satisfaction with that experience and consequently achieving customers' loyalty .Babin et al. (1994) advocate that shopping value including two dimensions that reveal the overall benefits of shopping activities which are utilitarian and hedonic shopping value. According to Bab in and Attaway (2000), utilitarian value reflects task-related worth, and hedonic value reflects worth found in the shopping experience itself, aside from task-related motives. 
Therefore, the paper's key objective is to consider the antecedents of loyalty to shopping malls in the retail area and identify what the relative importance of these attributes are from a customers' point of view, and if the shopping value affects the relationship between mall attributes and loyalty.

This research including six sections; the first section is the introduction followed by a literature review in section two. Section three will illustrate the research methodology. The fourth section will address the data analysis and hypotheses testing. Section five will report findings. Finally, section six will address limitations and future researches.

\section{Literature Review:}

\section{Mall attributes}

Previous researches have identified mall attributes as a multi-dimensional construct, which are varied across literature review.

A study conducted by Du et al., (2008b) classified mall attributes into eight dimensions; that are, atmosphere, convenience, facilities, institutional, merchandise, promotion, sales personnel and service. While Chebat et al., (2010) identified that attracting more people to a mall can be affected by access, atmosphere, price/promotion and assortment. Lately, Mafini \& Dhurup (2015) identified five factors; namely, store assistance, atmospherics, appeal, promotion and accessibility receive empirical attention.

Bearden (1977) stated that shopping mall atmosphere, friendliness of mall staff, location, and parking facilities are the main factors that influence consumer mall patronage. Amine and Cadenat (2003) pinpointed mall appearance, employees and promotional materials as components of a mall's image. While 
Miranda, et al.,(2005),found other attributes, which are, store's location, nature and quality of stocks, in-store promotions, sales personnel, physical attributes, convenience of store, atmospherics, and loyalty cards that influences consumer behavior.

In the current study, the researcher identifies seven factors that are most popular in previous researches in shaping the mall attributes, which are ;products, atmosphere, social interaction with other customers, convenience, service ,price, and social interaction with employees.

\section{Shopping value}

Shopping value is operationalized as two dimensions that indicate an assessment of the overall worth of shopping activity in terms of utilitarian and hedonic shopping value (Babin et al. 1994).

Davis and Hodges (2012) stated that Customers in shopping are motivated by a range of psychosocial needs that go beyond the acquisition of products and services. The fun and playfulness of shopping represent the hedonic value that shoppers gain during their shopping experience (Babin et al., 1994; Borges et al., 2013).

Recreational shoppers probably expect high levels of hedonic value which stems from the retailer's ability to provide customers with fun, excitement, fantasy, and inspiration (Babin et al., 1994; Diep and Sweeny, 2008; Nsairi, 2012). Fortunately, the mall through its interior design, décor, music, aromas, lighting, fun and entertainment programs, fashion shows, and events, as well as its physical environment, are able to create more hedonic value to shoppers than a stand-alone store can ( 
El-Adly, and Eid, 2015). Hedonic value was captured by five factors adapted from El-Adly, and Eid, (2015).

Utilitarian value reflects task-related worth; therefore, utilitarian customers see shopping trips from a work perspective as a mission to get what they need or want by purchasing a product; then the mission is completed (Babin et al., 1994; Cai and Shannon, 2012). In fact, malls provide their shoppers with this utilitarian value through their ability to meet customers' needs and wants via the plurality and variety of stores, products, restaurants, and service providers, etc. in a mall. Utilitarian value was captured by two factors adapted from Babin et al. (1994); and Diep and Sweeney (2008).

\section{Mall loyalty}

Most of previous researches in the shopping malls context stated that mall attributes have a positive impact on mall loyalty (Dick and Basu, 1994, Wallace et al., 2004).While Bowen and Chen (2001) found that loyalty towards a specific shopping mall is affected by the customers' experience of the characteristics of the mall. Accordingly it's very critical for the customers to keep their mind on the mall attributes which affect their repurchase intention. Shoppers are depending on different shopping malls meet their shopping needs (Nguyen et al., 2007).

Based on the inference theory by Nisbett and Ross, (1980), shoppers use whatever available information cues, such as atmospherics cues, to evaluate unavailable, missing, or difficult to evaluate information such as price, convenience, service, merchandise, other customers, and employees which affect shopping value and consequently affect their loyalty (Baker et al., 2002, Espinoza et al., 2004, Marie et al., 2011).

Relationship between Mall Attributes, shopping value (hedonic and utilitarian) and Loyalty 
Products:

It is an important image attribute because it acts as the 'core product' of shopping malls (Berman \& Evans, 2001). This is proved by Wakefield and Baker's study (1998), which underlined product and tenant variety as motivation that brings excitement in a shopping mall setting and thus influence the consumer's loyalty. Four merchandise-related items are frequently identified in the shopping center literature, namely assortment, quality, pricing, and styling or fashion (Frasquet \& Molla, 2001, Wong, et al., 2001, Bell, 1999; Finn \& Louviere, 1996; Ahn \& Ghosh, 1989; Weisbrod, et al., 1984).

A product is related to quality, selection, style and price of the products. In a retail outlet, such as shopping malls, that would relate to the tenant mix, which is described as the allocation of stores within a retail complex - in terms of space, price points, and mutual relationships in a way which leads to achieve benefits for the mall's management (ensure maximum

return on the initial investment), the tenants (benefit equally with the mall management in obtaining optimal traffic, crossshopping, prolonged visits, as well as increased productivity), and consumers (the variety and appeal, whilst also satisfying their demands) (Snyders and Cloete, 2010, Kim, et.al., 2012).

Shopping malls that offer larger variety in product categories make it easier to minimize time and effort associated with a shopping trip (Arnold and Reynolds, 2003), alleviate the shopping task (Dellaert et al., 1998). The products variety helps shopping malls cater to the heterogeneous tastes of their patrons (Dhar et al., 2001). It is thus reason to expect that product assortment provide utilitarian shopping value. Also, adventure shopping and idea shopping is identified as hedonic shopping value (Arnold and Reynolds, 2003) and presuppose width and breadth in product assortments. Retailer's product assortment is 
therefore expected to also provide hedonic shopping value and gaining customers' loyalty .From here we came up with the following hypotheses:

H1: There is a positive relationship between products, a) hedonic value, b) utilitarian value, and c) loyalty.

\section{Atmosphere:}

It is the first and most important attribute of the way a shopping mall is perceived, it can be considered as the most important marketing tool in shopping malls and it may affect shopper perceptions and behavior as well as make the shopping environment unique (Kotler, 1973). Atmospherics can be described by the elements (ambience, color, décor, music and layout) of the shopping mall that motivate customers to stay in the mall setting, browse, evaluate - and eventually buy (Yani and Foxal, 2006).Berman and Evans (2013) provided a more detailed outlay of the elements included in building atmosphere.

The broad outlay includes exterior factors, general interior factors, mall layout, as well as interior displays. Pan and Zinkhan (2006) verified that atmosphere significantly affected consumers' choice of a particular store, being fourth in ten significant drivers of retail venue patronage, while Teller and

Reutterer (2008) demonstrated that atmosphere could be an even more important factor to overall attractiveness of a shopping mall than the merchandise value itself. Chebat et al., (2010) stated that a pleasant atmosphere (color, music, crowding) contribute to shopping mall patronage (via "favorableness).

Utilitarian and hedonic values are not opposed but complementary and positively correlated. One can imagine a task-oriented shopper who would be at the bottom of the hedonic dimension. The reverse is less likely. Hedonic shoppers 
must also be motivated by perceived shopping goals (Michon and Chebat, 2004). Mall atmosphere induces a positive shopping affect that has a favorable impact on perceived shopping value, which in turn encourages shoppers to exhibit repeat purchase behaviors and consequently affecting customers' loyalty (Babin and Attaway, 2000; Parsons, 2011).

Ahmad (2012) approved these findings and confirmed that a positive relationship exists between entertainment and shoppers satisfaction with their shopping experience, and consequently leading to a high level of customer loyalty. Based on this discussion I will test the following hypotheses:

H2: There is a positive relationship between atmosphere, a) hedonic value, b) utilitarian value, and c) loyalty.

Social interaction:

It can be categorized into two groups; the first group is the impact of the mall staff on the customers, and the second group is the effect of the customers on each other which is regularly obvious in crowding situations and their behavior inside the mall, these two groups can be used by the management to build a long term relationship with the customers (Turley and Milliman, 2000, Backstrom and Johansson, 2006). The current research focuses on the relationships between customers and salespeople through the concept of personal interaction quality. Kwon, et al., (2016) stated that the shopping mall personnel's presence is used to connect the mall's attributes to the consumers.

The expected service level at the mall is always depending on the employees, because they are the persons who are contacting customers. Consequently, the salesperson's mood, appearance and credibility are important in order for good service encounters to occur. Good service encounters are crucial to achieve customer satisfaction and loyalty. In the 
meantime they suggested that the perception of similarity to other shoppers, both directly and indirectly affect customers' satisfaction with the shopping mall experience.

Given the finding that the mere presence of other shoppers can influence a customer's shopping experience, and retailers, consequently shopping mall managers should consider managing other consumers' presence in order to sustain the customers' loyalty and consequently enhance overall hedonic and utilitarian values of customers (Kim, et al., 2012).

Based on a social impact theory by Bibb Latané (1981), people affect one another in social situations. Through daily experiences such as embarrassment, persuasion, humor, and a plethora of other experiences, one can see the number of situations that are governed by the presence and actions of others. The impact can not only be observed visually, it also alters 'forces' within the target such as thoughts, attitudes, incentives and physiological state .So we can suppose the following hypotheses

H3: There is a positive relationship between social interaction with employees, a) hedonic value, b) utilitarian value, and c) loyalty.

H4: There is a positive relationship between social interaction with other customers, a) hedonic value, b) utilitarian value, and c) loyalty.

Convenience:

Convenience to consumers is the dominant factor in the design of shopping malls (Sit et al., 2003). Convenience or sometimes called accessibility is the ease of getting in and out of a shopping mall (Levy \&Weitz 1998), while other researches categorized convenience into two groups, micro-accessibility (parking facilities within the mall and ease of navigation within the shopping mall), and macro- accessibility (access road conditions to the mall and how far the shopping 
mall from the customers' place of work or living (Frasquet \&Molla, 2001, and Wong \& Yuan, 2001). Raimers and Clulow (2009) stated that "Time convenience" (a conglomerate of onestop shopping, extended trading hours, a compact environment, and localization close to where consumers live or work) appeared as the key factor in forming consumers' attitudes toward a shopping center.

Anselmsson (2006) articulated that convenience (including working hours) is the third most important effect over satisfaction and loyalty and the fifth largest influence over mallvisit frequency. Hence, working hours seem to act as a main influence over patronage behavior. Whereas Levy \&Weitz (1998) declared that shopping malls should be easily accessible to minimize the searching time and psychological costs of consumers, including stress and frustration and consequently achieving customers' loyalty.

In the study by Singh and Prashar (2013) convenience was the second factor (after ambiance) in building a shopping experience; while El Hedhli et al., (2013) argued that convenience is the third factor to drive shopping well-being, preceded by self-identification with a shopping mall and its atmosphere.

Since a mall, in essence, is a cluster of stores located in single building, a bundling or agglomeration effect, is produced which delivers additional utilitarian and hedonic shopping values to customers (Teller and Reutterer, 2008; Oppewal and Holyoake, 2004; Babin et al., 1994) in comparison to single retail outlet. Shopping values can be created by mall managers as a result of well managing the convenience attribute which leads to mall loyalty. The above discussion suggests the following hypotheses: 
H5: There is a positive relationship between Convenience, a) hedonic value, b) utilitarian value, and c) loyalty. Service:

Service is a vital part of the offer that is presented to consumers (Sit et al., 2003). Literature review has shown that there are two items related to the service attribute. The first item is food, such as having restaurants, availability of lunch or refreshments, and having better eat and drink places which affect hedonic value(Bellenger, et al., 1977, Nevin\& Houston, 1980, Wee's, 1986, Wakefield and Baker, 1998). The second item is safety and security which is including security, safe place, and personal security (Bellenger, et al., 1977, Wee 1986, Frasquet, Gil \&Molla, 2001).

According to Ahmad (2012) service quality has an impact on shopper satisfaction, and a higher level of service quality will provide a higher degree of shopping values which consequently affect loyalty. He stated that the expectations of customers should therefore dictate the level of service delivered and the competitive advantage will depend on how well the mall manages the personal expectations of their customers, and then to ensure that these expectations are met through reliable and satisfactory delivery in order to gain customers' loyalty.

While Berman and Evans (2013) found that physical facilities are related to the cleanliness, mall layout, and attractiveness, as well as shopping ease. These physical facilities relate to the core services; and they play a critical role in the consumers' choice as they affect hedonic and utilitarian values. Sit et al., (2003) and Hart et al. (2007) stated that customer service quality should therefore be considered a measurement of the general shopping mall image in that it represents the 'augmented product' that supports the basic merchandising function of the shopping mall and also adds value to the total enjoyment of the shopping experience, and consequently 
achieving customer's loyalty.As a result, the following hypotheses are derived:

H6: There is a positive relationship between service, a) hedonic value, b) utilitarian value, and c) loyalty.

Price:

Dorah and Job, (2014) specified that pricing is a relevantf actor to customers and retailers and illustrated how the mall managers considering the pricing strategy as one of the top five insistences in retail management, and how the owners of the stores in the shopping mall are actively involved in formulating pricing strategies to attract the customers to visit their stores. While Arpita et al., (2014) indicated that pricing is a very important attribute for customers, and discovered that consumer perception of price can positively or negatively affect buying behavior and consequently affect customer loyalty.

Malls' management and retail stores in malls can use a variety of price promotional strategies in order to target different segments, and consequently people shop in malls due to attractive offers, assortment mix, and displays and as a result, several malls report increase in sales during festivals because retail stores in malls offer incentives like discounts, free gifts, and price-offs. (Jackson, et.al, 2011) .The popularity of malls is attributed to retailers offering range of facilities that targeted different consumer segments, these bargain facilities like price discounts, rebates, freebies, and price cuts have been used by retailers to improve store patronage and loyalty .In addition the price promotion is an important strategy for improving sales and consumer satisfaction (Eddie et al., 2016).

Many researchers have verified that retailers in shopping malls can provide both utilitarian and hedonic values during the shopping experience which in turn affect customers' satisfaction and loyalty (Belk, 1979; Fischer and Arnold, 1990; Sherry, 
1990). For example, a consumer might be successful at finding the product that motivated the shopping trip at the first store visited and might also find that the product is being offered at a special sale price. Utilitarian value would then be derived from the consumer's success at quickly finding the product they needed, and hedonic value would be created by the excitement associated with the special sale price. However, Triandis (1977) notes that a high level of one type of value does not preclude a high level of the other, and vice versa. Accordingly, the following hypotheses can be developed:

H7: There is a positive relationship between price, a) hedonic value, b) utilitarian value, and c) loyalty.

Relationship between Shopping Values (Hedonic and Utilitarian) and Customer's Loyalty

A related theory of needs satisfaction suggests that all consumption events are capable of fulfilling needs at lower, more functional levels, as well as higher, more psychological levels (Oliver, 1997; Herzberg et al., 1959).

Hedonic and utilitarian shopping values are correlated to satisfaction (Babin et al., 1994, 2007; Jones et al., 2006) and consumers' repurchase behavior and loyalty (Babin and Attaway, 2000). Jones et al. (2006) assessed the relationship between shopping value and satisfaction and stated that satisfaction with the retailer, word of mouth and repurchase intention, are influenced more by hedonic value of shopping than by utilitarian value. Babin et al. (2007) realized that there is a significant positive relationship between utilitarian and hedonic shopping value sand customers' satisfaction and loyalty. Hence the following hypothesis is derived:

H8:There is a positive relationship between hedonic values and customers' loyalty. 
H9: There is a positive relationship between utilitarian values and customers' loyalty.

Based on the discussed theories, literature review, and hypotheses, Figure 1 shows the proposed model

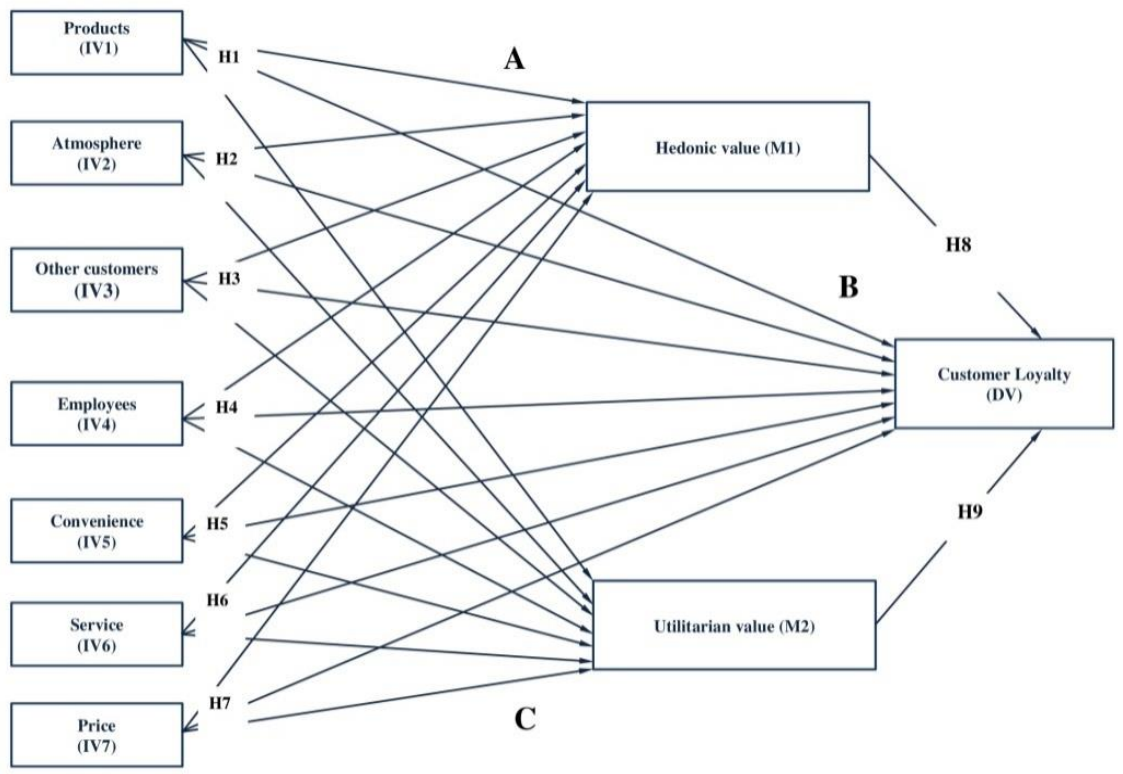

Figure (1) proposed model 


\section{Research methodology}

\section{Measurement}

Measures were adapted from an extensive review of relevant literature. Mall attributes adapted from Kumar et al., (1995), Allen and Meyer (1990) Westbrook and Oliver (1991), shopping value including two dimensions which are hedonic value including five factors adapted from El-Adly, and Eid, (2015) and utilitarian value including two factors adapted from Babin et al. (1994); and Diep and Sweeney (2008), and mall loyalty adapted from Ahmad (2012).

To assess content validity, the items are refined through expert review and pre-test. Their recommendations were used to modify, delete or improve the wording of items, and back translation was done from English to Arabic and from Arabic to English in turn. All constructs were measured using multi-item,

5 point Likert-type scales anchored from ' 1 '= strongly disagree to ' 5 ' $=$ strongly agree, a demographic section was also included at the end of the questionnaire.

\section{Sample and data collection}

Mall intercept interviews were conducted to collect data from regular shoppers at three shopping malls in great Cairo in Egypt. These shopping malls are namely Mall of Arabia (6th of October City), First Mall (Giza), and City Stars (Nasr City). Those three shopping malls were chosen because of four reasons: first, they are comparable in size and reputation. Secondly, they are located in different places which achieve the geographical coverage. Third, they are the largest shopping malls in Egypt in terms of number of stores and visitors(http://top10cairo.com/top-10-malls-in-cairo/). And finally, the visitors of each mall represent different levels of income. 
The shoppers were intercepted and welcomed to participate in the study as they left the shopping malls and were promised that the data collected would be used for entirely academic purposes. A total of 561 survey questionnaires were administered by professional data collectors in shoppers intercept techniques. The sample size 561 then was divided equally among the three shopping malls of the study. Accordingly each mall will have $33 \%$ of the sample size (i.e., 187). The questionnaires were launched on first of January, 2016 for two weeks during the week days and in different times during the day.

After data cleaning, 111 completed questionnaires were unusable because of missing data or inappropriate responses. The analysis was performed with an effective sample size of 450 respondents. Majority of respondents $(60 \%)$ were between 20 and 40 years old and $53 \%$ were women and $45 \%$ were men. The majority of the respondents (75\%) hada university level of education. All income ranges were well represented.

\section{Data analysis and results}

Researcher applied descriptive statistics using SPSS v.23 to test the data normality. Nevertheless, structural equation modeling has been applied especially, PLS-SEM modeling as implemented in Smart PLS 3.2.3. (Ringle et al., 2015); as PLS has found widespread use in marketing research (Hair et al., 2012; Henseler et al., 2009; Richter et al., 2016).

Researcher follows the systematic approach to validate the model (Hair et al., 2014; Henseler et al., 2009). All minimum requirements for outer loadings are met. For instance, all factor loadings of reflective indicators are higher than 0.71 (Malhotra, 2010); the value of both the composite reliability $C R$ is higher than 0.8 and convergent validity AVE is higher than 0.5. Also, discriminant validity for all constructs is established according to the new criterion HTMT $_{0.85}$ (Henseler et al., 2015). Consequently, the $R^{2}$ for customer loyalty, hedonic value and utilitarian value are very acceptable (see 
Table 1). To obtain inference statistics, researcher applied bootstrapping procedure with 5000 subsamples.

Moreover, researcher conducted the mediation test, since Sobel's approach has some drawbacks (Hair et al., 2014), author depend on the new mediation approach test (Preacher and Hayes, 2004 and 2008) to test the mediation effect and determine the exact effect size of the mediator/s. Giving more detailed analysis, researcher illustrate the steps with our case illustrations (see Table 2). VAF $<0.2$ means no mediation, $0.2<\mathrm{VAF}<0.8$ means partial mediation, $\mathrm{VAF}>0.8$ means full mediation (Hair et al., 2014).

Table (1) Structural and Measurement Model Evaluation

\begin{tabular}{|c|c|c|c|}
\hline \multicolumn{2}{|c|}{ Path coefficients } & \multirow[b]{2}{*}{ Values $\boldsymbol{\beta}_{(t-\text { value })^{S i g .}}$} & \multirow[b]{2}{*}{ Decision } \\
\hline Independent Variable & Dependent Variable & & \\
\hline \multirow{3}{*}{$\begin{array}{l}\text { Product } \\
\text { (IV1) }\end{array}$} & Customer loyalty (DV) & $-0.011_{(0.206)}{ }^{0.837}$ & Rejected \\
\hline & Hedonic value (M1) & $0.070_{(1.352)}{ }^{0.176}$ & Rejected \\
\hline & Utilitarian value (M2) & $0.116(1.871)^{0.061}$ & Rejected \\
\hline \multirow[t]{3}{*}{ Atmosphere (IV2) } & (DV) & $\left.\mathbf{0 . 0 8 3}_{(1.575)}\right)^{0.115}$ & Rejected \\
\hline & (M1) & $0.178_{(3.707)}{ }^{0.000}$ & Supported $* * *$ \\
\hline & (M2) & $0.125_{(2.081)}{ }^{0.038}$ & Supported* \\
\hline \multirow{3}{*}{$\begin{array}{l}\text { Interaction with } \\
\text { other customers } \\
\text { (IV3) }\end{array}$} & (DV) & $0.144_{(3.145)}{ }^{0.002}$ & Supported $* *$ \\
\hline & (M1) & $0.167_{(3.384)}{ }^{0.001}$ & Supported $* * *$ \\
\hline & (M2) & $0.058(1.086){ }^{0.278}$ & Rejected \\
\hline \multirow{3}{*}{$\begin{array}{l}\text { Interaction with } \\
\text { Employees (IV4) }\end{array}$} & (DV) & $0.125_{(2.374)} 0.018$ & Supported* \\
\hline & (M1) & $0.157_{(2.842)}{ }^{0.004}$ & Supported $* *$ \\
\hline & (M2) & $\mathbf{0 . 0 4 3}_{(0.749)}{ }^{0.454}$ & Rejected \\
\hline \multirow[t]{3}{*}{ Convenience (IV5) } & (DV) & $0.132_{(3.165)}{ }^{0.002}$ & Supported $* *$ \\
\hline & (M1) & $0.062_{(1.254)}^{0.210}$ & Rejected \\
\hline & (M2) & $0.194_{(3.421)}{ }^{0.001}$ & Supported $* * *$ \\
\hline \multirow{3}{*}{$\begin{array}{l}\text { Service } \\
\text { (IV6) }\end{array}$} & (DV) & $0.146(3.125)^{0.002}$ & Supported $* *$ \\
\hline & (M1) & $0.000_{(0.002)}{ }^{0.999}$ & Rejected \\
\hline & (M2) & $-0.089_{(1.761)}{ }^{0.078}$ & Rejected \\
\hline Price & (DV) & $0.109_{(2.410)}{ }^{0.016}$ & Supported* \\
\hline
\end{tabular}




\begin{tabular}{|c|c|c|c|}
\hline \multirow[t]{2}{*}{ (IV7) } & (M1) & $\left.0.053_{(1.012)}\right)^{0.312}$ & Rejected \\
\hline & (M2) & $\left.\mathrm{O.082}_{(1.447)}\right)^{0.148}$ & Rejected \\
\hline (M1) & (DV) & $0.249_{(5.056)^{0.000}}$ & Supported $* * *$ \\
\hline (M2) & (DV) & $0.084_{(1.132)^{0.258}}$ & Rejected \\
\hline Construct & AVE & $C R$ & $R^{2}$ \\
\hline (DV) & 0.537 & 0.873 & 0.452 \\
\hline (M1) & 0.511 & 0.931 & 0.245 \\
\hline (M2) & 0.509 & 0.860 & 0.157 \\
\hline Products (IV1) & 0.516 & 0.864 & \\
\hline Atmosphere (IV2) & 0.512 & 0.862 & \\
\hline $\begin{array}{l}\text { Interaction } \begin{array}{r}\text { with } \\
\text { other } \\
\text { (IV3) }\end{array} \text { customers } \\
\end{array}$ & 0.574 & 0.801 & \\
\hline $\begin{array}{ll}\text { Interaction } & \text { with } \\
\text { employees (IV4) } & \end{array}$ & 0.601 & 0.883 & \\
\hline Convenience (IV5) & 0.530 & 0.849 & \\
\hline Service (IV6) & 0.676 & 0.862 & \\
\hline Price (IV7) & 0.598 & 0.817 & \\
\hline
\end{tabular}

*** Significance level is $99.9 \%, \mathrm{P}$ value $<0.001, \mathrm{t}$ value \pm 3.21 (for path coefficient only)

$* *$ Significance level is $99 \%, \mathrm{P}$ value $<0.01$, t value \pm 2.58 (for path coefficient only).

* Significance level is $95 \%, \mathrm{P}$ value $<0.05, \mathrm{t}$ value \pm 1.96 (for path coefficient only).

Regarding the relationship between mall attributes(i.e., products, atmosphere, social interaction with employees, social interaction with other customers, convenience, service, and price) and the hedonic shopping value, findings indicated that atmosphere, social interaction with employees, and social interaction with other customers have a significant and positive effect on hedonic shopping value (path coefficients .178, .157, and .167 respectively), with $t$ values and significance level of 3.707; $p<.001,2.842 ; \mathrm{p}<.01$, and 3.384; $\mathrm{p}<.001$ respectively, which support $\mathrm{H} 2 \mathrm{a}, \mathrm{H} 3 \mathrm{a}$, and $\mathrm{H} 4 \mathrm{a}$.

Conversely, the results show that the relationship between products, convenience, service as well as price and the hedonic shopping value is not significant leading to reject $\mathrm{H} 1 \mathrm{a}$, H5a, H6a, and H7a. 
Also, regarding the relationship between mall attributes and the utilitarian shopping value, results indicated that atmosphere and convenience have a significant and positive impact on utilitarian shopping value (path coefficients .125, and .194 respectively), with $t$ values and significance level of 2.081 ; $\mathrm{p}<.05$, and 3.421; $\mathrm{p}<.001$ respectively, which support $\mathrm{H} 2 \mathrm{~b}$, and H5b.The findings, also, show that the relationship between products, social interaction with employees, social interaction with other customers, service, as well as price and the utilitarian shopping value is not significant leading to reject $\mathrm{H} 1 \mathrm{~b}, \mathrm{H} 3 \mathrm{~b}$, $\mathrm{H} 4 \mathrm{~b}, \mathrm{H} 6 \mathrm{a}$, and H7a.

Moreover, regarding the direct influence of mall attributes on customers' loyalty, the analysis shows that social interaction with employees, social interaction with other customers, convenience, service, and pricesignificantly and positively influence customers' loyalty(path coefficients .125 , $.144, .132, .146$, and .109 respectively), with $\mathrm{t}$ values and significance level of 2.374; $p<.05,3.145 ; \mathrm{p}<.01,3.165 ; \mathrm{p}<$ $.01,3.125 ; \mathrm{p}<.01$, and $109 ; \mathrm{p}<.05$ respectively, which support $\mathrm{H} 3 \mathrm{c}, \mathrm{H} 4 \mathrm{c}, \mathrm{H} 5 \mathrm{c}, \mathrm{H} 6 \mathrm{c}$, and H7c. The analysis, also, shows that the direct relationship between products as well as atmosphere and customers' loyalty is not significant leading to reject $\mathrm{H} 1 \mathrm{c}$, and $\mathrm{H} 2 \mathrm{c}$.

Moreover, regarding to hypothesis $8(\mathrm{H} 8)$, the results show that hedonic shopping value significantly and positively influences customers' loyalty (path coefficient $=.249, \mathrm{t}=5.056, \mathrm{p}$ $<.001$ ). This finding supports (H8). Finally, regarding to hypothesis 9 (H9), the results show that utilitarian shopping value does not predict customers' loyalty. This finding leads to reject $(\mathrm{H} 9)$. 
Table (2) Analytical results of the mediation test

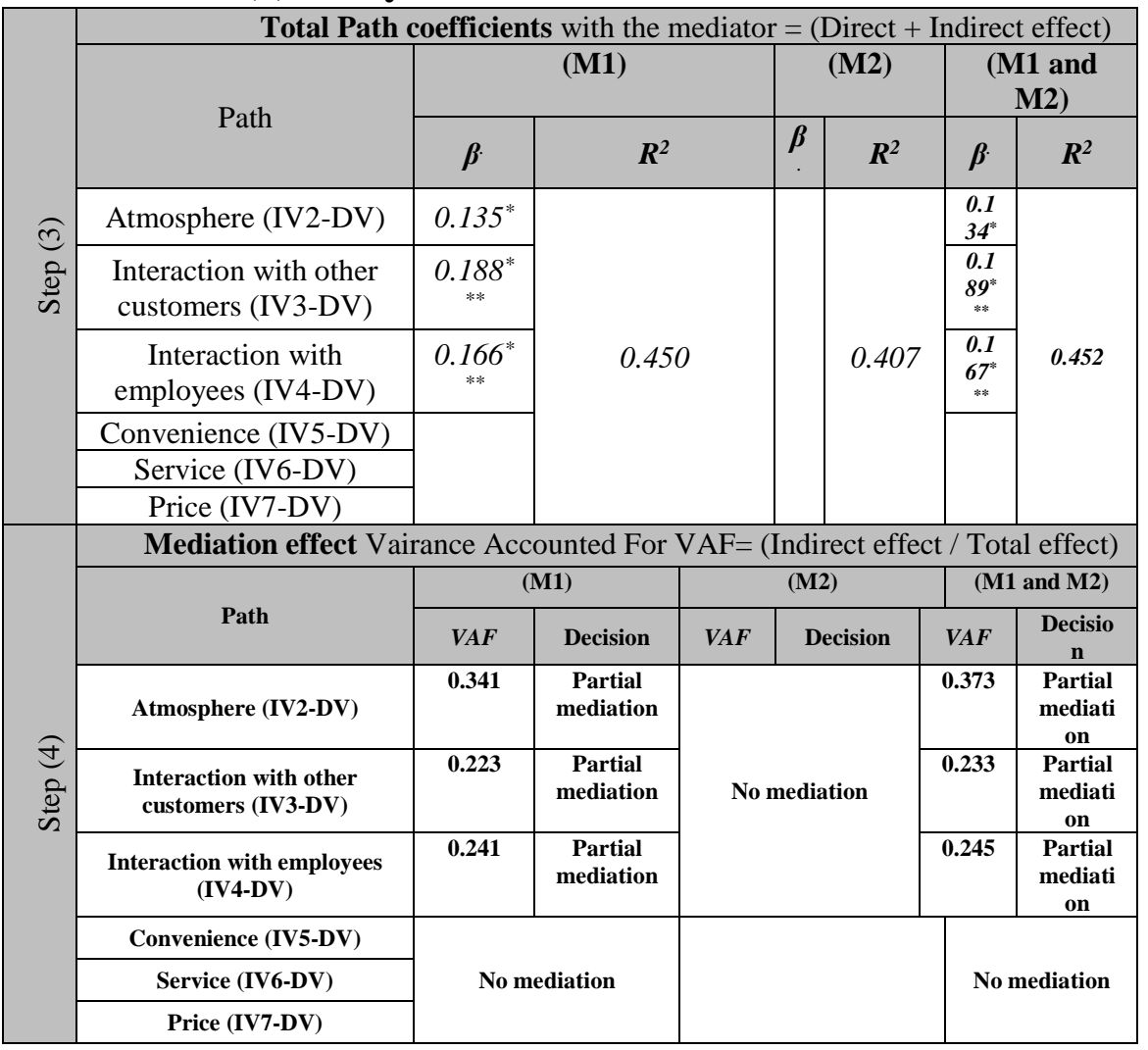

\begin{tabular}{|c|c|c|c|c|}
\hline \multirow{8}{*}{ Ð } & \multicolumn{2}{|c|}{ Direct Path coefficients without mediator } & \multirow[b]{2}{*}{$\boldsymbol{\beta}$} & \multirow[b]{2}{*}{ Decision } \\
\hline & $\begin{array}{l}\text { Independent Variable } \\
\text { IV }\end{array}$ & $\begin{array}{c}\text { Dependent } \\
\text { Variable DV }\end{array}$ & & \\
\hline & Products (IV1) & \multirow{6}{*}{ (DV) } & $0.012_{(0.232)^{0.816}}$ & $\begin{array}{c}\text { No mediation } \\
\text { effect }\end{array}$ \\
\hline & Atmosphere (IV2) & & $0.138_{(2.581)}{ }^{0.010}$ & \multirow{5}{*}{ Go to step (2) } \\
\hline & $\begin{array}{l}\text { Interaction with other } \\
\text { customers (IV3) }\end{array}$ & & $0.190_{(4.130)^{0.000}}$ & \\
\hline & $\begin{array}{c}\text { Interaction with } \\
\text { employees (IV4) }\end{array}$ & & $0.164_{(3.320)^{0.001}}$ & \\
\hline & Convenience (IV5) & & $\left.0.157_{(3.731)}\right)^{0.000}$ & \\
\hline & Service (IV6) & & $0.141_{(2.910)}{ }^{0.004}$ & \\
\hline
\end{tabular}




\begin{tabular}{|c|c|c|c|c|}
\hline & \begin{tabular}{|c|l} 
Price (IV7) & \\
\end{tabular} & & $\left.0.125_{(2.706)}\right)^{0.007}$ & \\
\hline \multirow{9}{*}{$\begin{array}{l}\text { d } \\
\frac{e}{\omega} \\
\frac{0}{\omega}\end{array}$} & \multicolumn{4}{|c|}{$\begin{array}{l}\text { Indirect Path coefficients with the mediator = (independent to mediator } \text {. } \\
\text { mediator to dependent) (see table } 1)\end{array}$} \\
\hline & \multirow{2}{*}{ 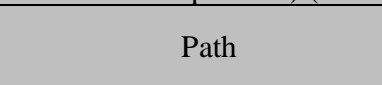 } & (M1) & (M2) & (M1 and M2) \\
\hline & & $\beta$ & $\beta$ & $\beta$ \\
\hline & Atmosphere (IV2-DV) & $0.046 * *$ & $0.010^{\text {not sig. }}$ & $0.050^{* *}$ \\
\hline & $\begin{array}{l}\text { Interaction with other } \\
\text { customers (IV3-DV) }\end{array}$ & $0.042^{* *}$ & $0.004^{\text {not sig. }}$ & $0.044^{* *}$ \\
\hline & $\begin{array}{l}\text { Interaction with employees } \\
\text { (IV4-DV) }\end{array}$ & $0.040^{*}$ & $0.015^{\text {not sig. }}$ & $0.041^{*}$ \\
\hline & Convenience (IV5-DV) & $0.016^{\text {not sig. }}$ & $0.015^{\text {not sig. }}$ & $0.025^{\text {non sig. }}$ \\
\hline & Service (IV6-DV) & $0.000^{\text {not sig. }}$ & $-0.008^{\text {not sig. }}$ & $-0.005^{\text {non sig. }}$ \\
\hline & Price (IV7-DV) & $0.014^{\text {not sig. }}$ & $0.006^{\text {not sig. }}$ & $0.017^{\text {non sig. }}$ \\
\hline
\end{tabular}

*** Significance level is $99.9 \%, \mathbf{P}$ value $<0.001, \mathrm{t}$ value \pm 3.21 (for path coefficient only).

** Significance level is $99 \%, \mathrm{P}$ value $<0.01$, $\mathrm{t}$ value \pm 2.58 (for path coefficient only).

* Significance level is $95 \%, P$ value $<0.05$, $t$ value \pm 1.96 (for path coefficient only).

\section{Mediation test}

In the first step, the PLS path model has been estimated without the potential mediator variables (i.e., hedonic and utilitarian shopping values). Table 2 shows these path coefficients' significance, which results from conducting the bootstrapping procedure with 5000 subsamples .The direct relationships between most of mall attributes and customers' loyalty are significant at $\mathrm{p}<.001$ or $\mathrm{p}<.01$, thus, the mediators may absorb some of these effects or the entire effects. The two exceptions are the relationship between product sand atmosphere dimensions and customers' loyalty which means that both hedonic and utilitarian shopping values don't mediate the relationship between products and atmosphere dimensions and customers' loyalty.

In the second step, the mediator variables have been included. A necessary (but not sufficient) condition is the significance of the relationships between all mall attributes and hedonic and utilitarian shopping values, as well as between hedonic and utilitarian shopping values and customers' loyalty. 
Based on results in table (1), the relationships that have been confirmed are first, between atmosphere and both hedonic and utilitarian shopping values, second, between social interaction with employees and with other customers and hedonic shopping value, third, between convenience and utilitarian shopping value, finally, between hedonic shopping value and customers' loyalty. Therefore, researcher concluded that hedonic shopping value doesn't mediate the relationship between convenience, service, and price attributes and customers' loyalty. Also, researcher concluded that utilitarian shopping value doesn't mediate the relationship between all mall attributes and customers' loyalty.

Based on results in table (2), which presents the significance analysis of indirect effects, it is clear that the indirect effects of atmosphere, social interaction with employees, as well as social interaction with other customers on customers' loyalty via the hedonic shopping value as a mediator are significant at $\mathrm{p}<.001$ or at $\mathrm{p}<.01$ or at $\mathrm{p}<.05$. Therefore, researcher has concluded that the hedonic shopping value mediates the relationship between atmosphere, social interaction with employees, as well as social interaction with other customers and customers' loyalty.

At final step, researcher assessed the strength of these mediations using the Variance Accounted For (VAF) as shown in table 2. The researcher concluded that $34.1 \%$ of atmosphere effect on customers' loyalty is explained via the hedonic shopping value mediator, and $37.3 \%$ of atmosphere effect on customers' loyalty is explained via both hedonic and utilitarian shopping values together and since the VAFs are greater than $20 \%$ but less than $80 \%$, these situations can be described as partial mediation. 
Also, $22.3 \%$ of social interaction with other customers effect on customers' loyalty is explained via the hedonic shopping value mediator, and $23.3 \%$ of social interaction with other customers effect on customers' loyalty is explained via both hedonic and utilitarian shopping values together and since the VAFs are greater than $20 \%$ but less than $80 \%$, these situations can be described as partial mediation.

Finally, $24.1 \%$ of social interaction with employees effect on customers' loyalty is explained via the hedonic shopping value mediator, and $24.5 \%$ of social interaction with employees effect on customers' loyalty is explained via both hedonic and utilitarian shopping values together and since the VAFs are greater than $20 \%$ but less than $80 \%$, these situations qan Biscuscribsed aspartial mediation implications

The research was done using a theoretical framework developed based on previous studies. The main purpose of this study was to investigate the relationships between mall attributes, shopping value and loyalty. Statistical analyses were conducted to answer key research questions. Results from the hypotheses testing suggest the following information:

Testing whether there is a positive relationship between mall attributes and shopping value (both hedonic and utilitarian) also has been presented. Regarding the relationship between mall attributes and hedonic shopping value, of the seven mall attributes in the model, only atmosphere, social interaction with employees, and social interaction with other customers have a significant and positive effect on hedonic shopping value. Therefore, this result complies with the results of (Parsons, 2011 and Ahmad, 2012). Also, regarding the relationship between mall attributes and the utilitarian shopping value, results indicated that of the six mall attributes only atmosphere and convenience have a significant and positive impact on utilitarian shopping value. This result is in compliance with the literature 
(e.g.Chebat et al., 2010; Singh and Prashar, 2013; El Hedhli et al., 2013).

Examining whether there is a positive relationship between malls attributes and customers' loyalty have been addressed. Most mall attributes were found to affect positively and significantly the customers' loyalty. The attributes which have the strongest significant and positive relationship with loyalty were respectively as follows: social interaction with

employees, interaction with other customers, convenience, service, and price. This finding is supported by (Johansson, 2006; Kim, et al., 2012; Kwon et al., 2016; Anselmsson, 2006; Ahmad, 2012; Hart et al., 2007; Arpita et al., 2014).The other mall attributes in the model (product and atmosphere) were not statistically significant and thus did not provide a significant direct contribution toward loyalty. Thus, building customers' loyalty will result from: First building mall attributes especially personal interaction with employees by ensuring that all sales assistants are equipped with essential skills that will enable them to be more courteous and helpful. Second, social interaction with other surroundings customers should be focused by attracting comparable customers to mall, attractive atmosphere, and making attractive range of products available. Third, convenience should be emphasized as the results showed that customers care about convenience as visiting malls looks like a journey from customers' view of point. Fourth, mall managers should stress on services like: Flexible return/exchange policies; availability of E- retailing service; handling complaints; free spaces for waiting and special events. Finally, providing competitive prices was also found to have a positive impact on customer's loyalty and hence, should be adopted.

Testing whether there is a positive relationship between shopping value and loyalty has also been conducted. In 
accordance with the literature, the results showed that hedonic shopping value significantly and positively influences customers' loyalty(e.g. Babin and Attaway, 2000; Jones et al., 2006; Babin et al. 2007). However, the results contradict with the literature showing that utilitarian shopping value does not predict customers' loyalty(e.g. Jones et al., 2006; Babin et al., 2007). This result highlights the importance of hedonic shopping value in building mall loyalty.

In terms of mediation effect, only hedonic shopping value has a partial mediation effect between some mall attributes (atmosphere, social interaction with employee sand social interaction with other customers) and loyalty which agreed with

the results of (Babin et al., 1994; Diep and Sweeny, 2008; Nsairi, 2012;El-Adly, and Eid, 2015).Therefore, it is important for retail management to increase their ability to provide customers with fun, excitement, fantasy, and inspiration. This can be achieved in the mall through its interior design, décor, music, aromas, lighting, fun and entertainment programs, fashion shows, and events, as well as its physical environment.

To conclude, the results of this research agreed to a great extent with the literature review and emphasized that mall attributes have a significant direct or indirect positive impact on achieving customer loyalty. The indirect impact of mall attributes on loyalty can be through strengthening hedonic shopping value which has a significant positive impact on loyalty.

The main contributions of this study are thus the development and empirical validation of a hypothetical model that predicts positive relationship between mall attributes, shopping value and loyalty and also, the identification of attributes that play the most important roles. The other contribution that this study intends to make is that marketing 
managers and professionals need to pay attention to the importance of investments in shopping value and equip themselves with more understanding of the mall attributes that have the highest impact on loyalty as well as the partial mediation role played by shopping value between mall attributes and loyalty.

Limitations and future research:

The study has some limitations that may provide future research opportunities. First, cross-sectional data was used for the study. So testing the proposed model using a longitudinal study design may be required . Second, the proposed model was not intended to test all of antecedents and consequences of shopping value. Therefore, other factors contribute to the development of shopping value and loyalty should be included in future research. Third, similar studies could be conducted that include other regions of Egypt with different subcultures, social classes and lifestyles. Fourth, investigating the views of line managers inside investigated malls and who are impacted by the mall attributes and shopping value need to be considered in future research. A further recommendation would be to conduct a qualitative study which would use interviews to gain an understanding of the degree to which customers are loyal due to shopping value and mall attributes. Finally, other suggested point is to study different dimensions of shopping value and their effects on loyalty.

\section{References}

1. Ahmad, A.M.K. (2012). Attractiveness factors influencing shoppers' satisfaction, loyalty and word of mouth: an empirical investigation of Saudi Arabia Shopping Malls. International Journal of Business Administration, 3(6), 101-112. 
2. Ahn, K. H., \&Ghosh, A. (1989). 'Hierarchical models of store choice'. International Journal of Retailing, vol. 4, no. 5, pp. 39-52.

3. Amine, A. and Cadenat, S. (2003). Efficient retailer assortment: a consumer choice evaluation perspective. International Journal of Retail \& Distribution Management, Vol. 31 No. 10, pp. 486-97.

4. Arnold, M.J. and Reynolds, K.E. (2003). "Hedonic shopping motivations", Journal of Retailing, Vol. 79 No. 2, pp. 77-95.

5. Arpita Khare, Dhiren Achtani, and Manish Khattar. (2014). "Influence of price perception and shopping motives on Indian consumers' attitude towards retailer promotions in malls", Asia Pacific Journal of Marketing and Logistics, Vol. 26, Iss 2, pp. $272-295$.

6. Babin, B., Darden, W., Griffin, M., 1994. Work and/or fun: measuring hedonic and utilitarian shopping value. Journal of Consumer Research 20, 644-656.

7. Babin, B., Gonzales, C., Watts, C., 2007. Does Santa have a great job? Gift shopping value and satisfaction. Psychology and Marketing, 24, 895-917.

8. Babin, B.J. and Attaway, J. (2000), “Atmospheric affect as a tool for creating value and gaining share of customer", Journal of Business Research, Vol. 49 No. 2, pp. 91-100.

9. Backstrom, K. and Johansson, U. (2006). Creating and Consuming Experiences in Retail Store Environments: Comparing Retailer and Consumer Perspectives, Journal of Retailing and Consumer Services, 13, 417-430. 
10. Baker, Julie, Parasuraman, A., Grewal, Dhruv, Voss, Glenn B. (2002). The Influence of multiple store environment cues on perceived merchandise value and patron- age intentions. Journal of Marketing 66 (2), 120 141.

11. Bearden, William O. (1977). Determinant Attributes of Store Patronage: Downtown versus Outlying Shopping Centers. Journal of Retailing, pp. 15-22.

12. Belk, R., 1979. Gift giving behavior. In: Sheth, J. (Ed.), Research in Marketing, vol. 2. JAI press, Greenwich, CT, pp. 95-126.

13. Bell, S. (1999). 'Image and consumer attraction to intraurban retail areas: an environmental psychology approach', Journal of Retailing and Consumer Services, vol. 6, pp. 67-78.

14. Bellenger, D., Robertson, D. \& Greenberg, B. (1977). 'Shopping center patronage motives'. Journal of Retailing, vol. 53, no. 2, summer, pp. 29-38.

15. Berman, B. \& Evans, J. (2013). Retail Management: A Strategic Approach, 8th edition, Prentice Hall, United States.

16. Berman, B. \& Evans, J.R. (2013). Retail management: a strategic approach. 12th ed. Boston: Pearson.

17. Bloch, P., Bruce, G., 1984. The leisure experience and consumer products: an investigation of underlying satisfactions. Journal of Leisure Research, 16, 74-88.

18. Bloch, P., Bruce, G., 1984. The leisure experience and consumer products: an investigation of underlying satisfactions. Journal of Leisure Research 16, 74-88. 
19. Borges, A., Babin, B. and Spielmann, N. (2013), "Gender orientation and retail atmosphere: effects on value perception", International Journal of Retail \& Distribution Management, Vol. 41 No. 7, pp. 498-511.

20. Bowen, J. T., \& Chen, S. L. (2001). The Relationship between Customer Loyalty and Customer Satisfaction. International Journal of Contemporary Hospitality Management, pp. 213-217.

21. Cai, Y. and Shannon, R. (2012), "Personal values and mall shopping behaviour: the mediating role of intention among Chinese consumers", International Journal of Retail \& DistributionManagement, Vol. 40 No. 4, pp. 290-318.

22. Chebat, J.-C., Sirgy, M. J., \&Grzeskowiak, S. (2010). How can shopping mall management best capture mall image? Journal of Business Research, 63, pp.735-740.

23. Davis, L. and Hodges, N. (2012), "Consumer shopping value: an investigation of shopping trip value, in-store shopping value and retail format", Journal of Retailing and ConsumerServices, Vol. 19 No. 2, pp. 229-239.

24. Dellaert, B., Arentze, T. and Bierlaire, M. (1998), "Investigating consumers' tendency to combine multiple shopping purposes and destinations", Journal of Marketing Research, Vol. 3 No. 2, pp. 177-88.

25. Dhar, S.K., Hoch, S.J. and Kumar, N. (2001), "Effective category management depends on the role of the category", Journal of Retailing, Vol. 77 No. 2, pp. 165-84.

26. Dick, A. and Basu, K. (1994). Customer loyalty: towards an integrated framework. Journal of the Academy of Marketing Science, 22 (2), 99-113 
27. Diep, V.S. and Sweeney, J.C. (2008), "Shopping trip value: do stores and products matter?", Journal of Retailing and Consumer Services, Vol. 15 No. 5, pp. 399409.

28. Dorah Dubihlela and Job Dubihlela. (2014). Attributes of Shopping Mall Image, Customer Satisfaction and Mall Patronage for Selected Shopping Malls in Southern Gauteng, South Africa. Journal of Economics and Behavioral Studies, Vol. 6, No. 8, pp. 682-689.

29. Du Preez, R., Visser, E., \& Van Noordwyk, H.J. (2008b). Store image: scale implementation part 3. South African Journal of Industrial Technology, 34(2), 69-78.

30. Eddie Chi, Man Hui Ning, Ning Ka Kwan, and Kevin Chan. (2016)."The critical factors of shopping malls in urban complexes in China". Facilities, Vol. 34 Iss 11/12 pp. $33-65$.

31. El Hedhli, K., Chebat, J.-C., \&Sirgy, M. J. (2013). Shopping well-being at the mall: Construct, antecedents, and consequences. Journal of Business Research, 66(7), 856-863.

32. El-Adly , Mohammed Ismail, and Eid, Riyad, (2015) "Measuring the perceived value of malls in a non- Western context: the case of the UAE", International Journal of Retail \& Distribution Management, Vol. 43 Issue: 9, pp.849-869.

33. El-Adly, M. I. (2007). Shopping malls attractiveness: A segmentation approach. International Journal of Retail and Distribution Management, Vol. 35, No. 11, 936-950. 
34. Espinoza, Francine Liberali, Guilherme, D'Angelo, Andre'. (2004). Testing the influence of retail atmosphere on store choice criteria, perceived value and patronage intentions. In: Proceedings of the Winter Educator's Conference, vol.15. American Marketing Association, Scottsdale, USA, pp.120-125.

35. Finn, A. \& Louviere, J. (1996). 'Shopping center image, consideration, and choice: anchor store contribution'. Journal of Business Research, vol. 35, pp. 241-251.

36. Fischer, E., Arnold, S., 1990. More than a labor of love: gender roles and christmas gift shopping. Journal of Consumer Research, 17, 333-345.

37. Fischer, E., Arnold, S., 1990. More than a labor of love: gender roles and Christmas shopping. J. Consum. Res. 17, 333-345.

38. Fischer, E., Arnold, S., 1990. More than a labor of love: gender roles and christmas gift shopping. Journal of Consumer Research 17, 333-345.

39. Frasquet, M., Gil, I., Molla, A. (2001). 'Shopping-center selection modeling: a segmentation approach'. The International Review of Retail, Distribution and Consumer Research, vol. 11, no. 1, pp. 23 - 38.

40. Frasquet, M., Gil, I., Molla, A. (2001). 'Shopping-center selection modeling: a segmentation approach'. The International Review of Retail, Distribution and Consumer Research, vol. 11, no. 1, January 2001, pp. 23 - 38.

41. Hair Jr, J. F., Hult, G. T. M., Ringle, C., \& Sarstedt, M. (2014). A primer on partial least squares structural equation modeling (PLS-SEM). Sage Publications. 
42. Hair, J. F., Sarstedt, M., Ringle, C. M., and Mena, J. A. (2012). An Assessment of the Use of Partial Least Squares Structural Equation Modeling in Marketing Research. Journal of the Academy of Marketing Science, 40(3), 414433.

43. Hart, C., Farrell, A.M., Stachow, G., Reed, G \&Cadogan, J.W. (2007). Enjoyment of the shopping experience: impact on customers re-patronage intentions and gender influences. The Service Industry Journal, 27(5):583-604.

44. Henseler, J., Ringle, C. M., \& Sarstedt, M. (2015). A new criterion for assessing discriminant validity in variancebased structural equation modeling. Journal of the Academy of Marketing Science, pp.1-21.

45. Henseler, J., Ringle, C. M., \& Sinkovics, R. R. (2009). The use of partial least squares path modeling in international marketing. Advances in International Marketing, vol. 20, pp. 277-320.

46. Herzberg F, Mausner B, Snydermann BB. The motivation to work, New York: Wiley; 1959.

47. Jackson, V., Stoel, L., and Brantley, A. (2011). Mall attributes and shopping value: differences by gender and generational cohort. Journal of Retailing and Consumer Services, 18(1), pp. 1-9.

48. Jones, M., Reynolds, K., Arnold, M., 2006. Hedonic and utilitarian shopping value: investigating differential effects on retail outcomes. Journal of Business Research, 59, 974-981.

49. Kim, H-Y., Kang, J-Y.M. \& Johnson, K.K.P. (2012). Effect of consumer relationship proneness on perceived 
loyalty program attributes and resistance to change. International Journal of Retail and Distribution Management, 40(5):376-387.

50. Kotler, P. (1973). Atmospherics as a marketing tool, Journal of Retailing, 49(4):48-64.

51. Kwon, H., Ha, S., Im, H. (2016). The impact of perceived similarity to other customers on shopping mall satisfaction. Journal Of Retailing And Consumer Services, 28(1),304-309.

52. Lang, B. and Colgate, M. (2003). "Relationship quality, on-line banking and the information technology gap". International Journal of Bank Marketing, Vol. 21 No. 1, pp. 29-37.

53. Levy, M. and Weitz, B. (1998). Retailing Management, 3rd ed., McGraw-Hill, United States.

54. Malhotra, N. K. (2010). Marketing research: An applied orientation, 6th Global edition, Upper Saddle River, NJ: Pearson.

55. Marie-Claude Massicotte, Richard Michon, Jean-Charles Chebat, M. Joseph Sirgy, Adilson Borges. (2011). Effects of mall atmosphere on mall evaluation: Teenage versus adult shoppers. Journal of Retailing and Consumer Services 18 (2011) 74-80

56. Michon, R. and Chebat, J.-C. (2004), "Cross-cultural mall shopping values and habitats: a comparison between English- and French-speaking Canadians", Journal of Business Research, Vol. 57 No. 8, pp. 883-892. 
57. Miranda, M.J., Konya, L., Havrila, I. (2005). Shoppers Satisfaction Levels are not the Only Key to Store Loyalty. Marketing Intelligence and Planning, 23 (2), 220-232

58. Nevin, J. \& Houston, M. (1980). 'Image as a component of attraction to interurban shopping areas'. Journal of Retailing, vol. 56, no. 1, Spring, pp. 77-93.

59. Nguyen, T.T.M, Nguyen, T.D. and Barrett, N.J. (2007). Hedonic Shopping Motivations, Supermarket Attributes, and Shopper Loyalty in Transitional Markets: Evidence from Vietnam. Asia Pacific Journal of Marketing, Vol. 19, No. 3, pp. 227-239.

60. Nisbett, Richard, Ross, Lee, (1980). Human Inference: Strategies and Shortcomings of Social Judgment. PrenticeHall, Englewood Cliffs, NJ; Toronto.

61. Nsairi, Z.B. (2012), "Managing browsing experience in retail stores through perceived value: implications for retailers", International Journal of Retail \& Distribution Management, Vol. 40 No. 9, pp. 676-698.

62. Oliver R. Satisfaction: a behavioral perspective on the consumer. New York: McGraw-Hill; 1997.

63. Oppewal, H. and Holyoake, B. (2004), "Bundling and retail agglomeration effects on shopping behaviour", Journal of Retailing and Consumer Services, Vol. 11 No. 2, pp. 61-74.

64. Pan, Y., \&Zinkhan, G. M. (2006). Determinants of retail patronage: A meta-analytical perspective. Journal of Retailing, 82(3), 229-243. 
65. Parsons, A.G. (2011), "Atmosphere in fashion stores: do you need to change?", Journal of Fashion Marketing and Management, Vol. 15 No. 4, pp. 428-445.

66. Preacher, K. J., \& Hayes, A. F. (2004). SPSS and SAS procedures for estimating indirect effects in simple mediation models. Behavior research methods, instruments, \& computers, 36(4), 717-731.

67. Preacher, K. J., \& Hayes, A. F. (2008). Asymptotic and resampling strategies for assessing and comparing indirect effects in multiple mediator models. Behavior research methods, 40(3), 879-891. Prentice-Hall.

68. Reimers,V., Clulow,V. (2009). Retail centers: It's time to make them convenient. International Journal of Retail and Distribution Management 37 (7), 541-562.

69. Richter, N. F., Sinkovic, R. R., Ringle, C. M., and Schlägel, C. (2016). A Critical Look at the Use of SEM in International Business Research. International Marketing Review, forthcoming.

70. Ringle, C. M., Wende, S., and Becker, J.-M. (2015). "Smart PLS 3." Boenningstedt: Smart PLS GmbH, http://www.smartpls.com.

71. Sherry, J., 1990. A sociocultural analysis of a Midwestern flea market. J. Consum. Res. 17, 13-30.

72. Sherry, J., McGrath, M., Levy, S., 1993. The dark side of the gift. Journal of Business Research, 28, 225-245.

73. Sherry, J., McGrath, M., Levy, S., 1993. The dark side of the gift. Journal of Business Research 28, 225-245.

74. Singh, H., \&Prashar, S. (2013). Anatomy of shopping experience for malls in Mumbai: A confirmatory factor 
analysis approach. Journal of Retailing and Consumer Services, pp.15-20.

75. Sit, J., Merrilees, B. \& Birch, D. (2003). Entertainment seeking shopping center patrons: the missing segments. International Journal of Retail and Distribution Management, 31(2):80-94.

76. Snyders, V. \&Cloete, C. (2010). Tenant mix. In Cloete, C.E. (ed.) Shopping center management in South Africa. 4th ed. Sandton: South African Council of Shopping Centers.

77. Storbacka, K., Strandvik, T. and Christian, G. (1994). "Managing customer relationships for profit: the dynamics of relationship quality". International Journal of Service Industry Management, Vol. 5 No. 5, pp. 21-38.

78. Teller, C. and Reutterer, T. (2008), "The evolving concept of retail attractiveness: what makes retail agglomerations attractive when customers shop at them?", Journal of Retailing and Consumer Services, Vol. 15 No. 3, pp. 127143.

79. Teller, C., \&Reutterer, T. (2008). The evolving concept of retail attractiveness: What makes retail agglomerations attractive when customers shop at them?. Journal of Retailing and Consumer Services, 15(3), 127-143.

80. Terawatanavong, C. and Quazi, A. (2006). "Conceptualizing the link between national cultural dimensions and B2B relationships". Asia Pacific Journal of Marketing and Logistics, Vol. 18 No. 3, pp. 173-83. 
81. Terblanche, N.S. (1999). The perceived benefits derived from visits to a super-regional shopping center: An exploratory study. South African Journal of Business Management, Vol. 30, No. 4, pp. 13-20.

82. Triandis, H., 1977. Interpersonal Behavior. Brooks/Cole, Monterey. US Census Bureau, 2000. Census of the United States available online: http://www. census.gov.

83. Turley, L.W. and Miliman, R.E. (2000), - ). Atmospheric Effects on Shopping Behavior: A Review of the Experimental Evidencell, Journal of Business Research, Vol. 49, No. 2, pp. 193-211.

84. Wakefield, L., \& Baker, J. (1998). Excitement at the mall: determinants and effects on shopping response. Journal of Retailing, 74(4), 515-39.

85. Wallace MT, Perrault TJ, Jr, Hairston WD, Stein BE. (2004). Visual experience is necessary for the development of multisensory integration. J Neurosci ; 24 (4) 9580-9584.

86. Wee, C. H. (1986). Shopping area image: its factor analytic structure and relationships with shopping trips and expenditure behavior'. Advances in Consumer Research, pp. 48-52.

87. Weisbrod, G., Parcells, R. \& Kern, C. (1984). 'A disaggregate model for predicting shopping area market attraction'. Journal of Retailing, vol. 60, no. 1, spring, pp. 65-83.

88. Wong, K. M., Lu, Y., and Yuan, L. L. (2001). SCATTR: an instrument for measuring shopping center 
attractiveness'. International Journal of Retail \& Distribution Management, vol. 29, no. 2, pp. 76-86.

89. www.http://top10cairo.com/top-10-malls-in-cairo/.

90. Yani, M.M. \& Foxall, G.R. (2006). The emotional power of place: the fall and rise of dominance in retail research. Journal of Retailing and Consumer services, 13(6):403416. 